\title{
Spatiotemporal Variations in Temperature Accumulation, Phenological Development and Grain Yield of Maize (Zea mays L.)
}

\author{
Abdul Hamid ${ }^{1}$, M. Ali Akbar ${ }^{1}$, M. Jafar Ullah², Mong Sanue Marma ${ }^{3}$, M. Mahbubul Islam ${ }^{4}$ \\ Jatish C. Biswas ${ }^{1} \&$ M. G. Neogi ${ }^{1}$ \\ ${ }^{1}$ Agrarian Research Foundation, Lalmatia, Dhaka, Bangladesh \\ ${ }^{2}$ Agronomy Department, Sher-e-Bangla Agricultural University, Dhaka, Bangladesh \\ ${ }^{3}$ Hill Cotton Research Station, Cotton Development Board, Balaghata, Bandarban, Bangladesh \\ ${ }^{4}$ Soil and Water Conservation Research Center, Meghla, Bandarban, Bangladesh \\ Correspondence: Abdul Hamid, Agrarian Research Foundation, House 5/10B, Block A, Lalmatia, Dhaka 1207, \\ Bangladesh. Tel: 88-2-912-0802. E-mail: hamid50.arf@gmail.com
}

Received: August 6, 2019 Accepted: October 2, $2019 \quad$ Online Published: December 15, 2019

doi:10.5539/jas.v12n1p46 URL: https://doi.org/10.5539/jas.v12n1p46

The research was partially financed by Krishi Gobeshona Foundation, Dhaka, Bangladesh.

\begin{abstract}
Planting date effect on phenological development, temperature accumulation and grain yield of maize was evaluated at three locations of Bangladesh differing in environmental conditions. Marked variations were observed in days to attaining phenological stages, temperature accumulation, duration of growth stages and grain yield across locations and planting dates. October planted maize in Bandarban completed its life cycle in 116 days while February planted maize in Kaharol suffered from high temperatures. December planted maize in Birganj experienced cool weather in vegetative phase and nearly optimal temperatures during reproductive phase. High temperatures hastened maturity reducing the duration of reproductive growth. Early planted maize produced the highest grain yield. Higher grain yield was positively related with the duration of reproductive growth phase. Late planting reduced maize grain yield mainly through lowering the number of kernels per ear and reducing kernel weight.
\end{abstract}

Keywords: GDD, maize, phenology, planting date, locations, temperature stress

\section{Introduction}

Located between $20^{\circ} 34^{\prime}$ and $26^{\circ} 38^{\prime} \mathrm{N}$ and between $88^{\circ} 01^{\prime}$ and $92^{\circ} 42^{\prime} \mathrm{E}$, Bangladesh is a deltaic country covering a geographical area of $147,570 \mathrm{~km}^{2}$. A fair degree of diversity in climatic conditions and agro-ecological settings exist in the country. Air temperatures in the northern districts are usually higher than in southern districts during summer months and in the winter months the opposite is true. Generally, higher the latitudes greater is the diurnal and intra-annual variations in temperatures. Variation in agro-ecological conditions influences cropping systems across locations. Highly intensive cropping is practiced throughout the country except in the south-eastern, undulating rugged terrain of Chittagong Hill Tracts (CHT) where cropping intensity is among the lowest.

Highly intensive cropping is practiced in Bangladesh. Climatic conditions in the country favor growing diversified crops year-round. Increasing food demand due to rising population and availability of high yielding crop varieties (HYV) of short maturity duration coupled with expansion of irrigation system helped crop intensification almost throughout the country; with cropping intensity varying from $160 \%$ to over $300 \%$ depending on location, topography and climatic conditions. Demand and profitability of the crop and the crop duration are among the prime considerations of farmers in including a new crop altering the existing cropping systems. Finding window of fitting a new crop into the existing cropping systems requires understanding of crop phenology and environmental conditions of the location.

Cropping intensity in the northern districts increased by 200 per cent in the last few decades. In Dinajpur and adjoining districts, for example, where farmers used to grow only one crop of rice with low yielding traditional 
varieties in 1970s are now practicing three- crop system growing wheat, potato or rapeseed after harvesting early maturing HYV aman (autumn) rice in November. Maize (Zea mays L.), a recently introduced cash crop, is now being extensively grown in the northern districts to support rapidly expanding feed industry. In the CHT, less than $6 \%$ of the area is suitable for crop production. Traditional jhum or shifting cultivation is practiced in the hills during wet season. Valley lands are intensively used for crop production but the area of valley land is extremely limited. The region remains food-deficit since time immemorial. Traditionally the ethnic peoples in the CHT consume maize as secondary staple next to rice. They use maize ears harvesting at dough stage. This being a popular food item, hill farmers harvest maize prior to maturity without waiting for grains. This shortens the growing season by about 3-4 weeks.

Development of poultry, fish and livestock industry and consequential demand for feed triggered adoption and quick dissemination of maize as a cash crop in the northern districts. In response to increasing food demand farmers expanded wheat production in the region during dry season; but yield decline due to rising temperature and incidence of diseases caused reduction of area and production of wheat in recent years giving way to maize. Now maize is planted as an important cash crop to over 0.47 million ha producing about 3.1 million tons annually (BBS, 2018). While maize is planted in dry season in major growing areas in northern Bangladesh, it is grown in the CHT throughout the year (Akbar et al., 2016). Either in the plains or in the hills maize grain yield in Bangladesh is fairly high that ranges between 5.5 tons to 11.5 tons per ha across locations and seasons (Islam, Mahfuz, Sarker, Ghosh, \& Ali, 2014; Akbar et al., 2016). Maize yield in Bangladesh is thus among the highest in Asia (Timsina \& Majumdar, 2012). For crop intensification and gettinghigh yield and profit, timely planting and harvesting of crops is farmers' prime consideration.

Growth and development of maize has important bearing on the duration of growing season and yield. Plant growth and development are inter-related but different processes. Growth is an irreversible process of increase in weight or size while change in growth stage is referred to as development. Staging plant development and predicting growth stages is an important tool for crop management. Plant growth is governed by photo-thermal conditions while development is largely temperature driven (Warrington \& Kanemasu, 1983). Temperature regulated growth staging of crop plants are generally termed as phenology. Understanding of phenological development of crop is fundamental to successful crop production practices. Phenology being highly variable and responsive to long-term variation in climate (White, Thornton, \& Running, 1997), investigation of temporal changes in phenology is essential for understanding crop response and adaptation to climate change. Assessment of phenological development may contribute to positioning maizein Bangladesh responding to changing climate.

Prediction of maize development with respect to temperatures has been in practice (Kumudini et al., 2014). Heat unit or thermal time or growing degree day (GDD) is a widely used concept (Daynard, 1972; Major et al., 1983). GDD is widely used in predicting crop phenological development and maturity. For a particular crop GDDis calculated as the residue of daily mean air temperature and a base temperature of that crop. GDD varies among different crop types, varieties, and hybrids for different locations. Maize is a tropical crop and can be planted in well drained medium high lands throughout the year provided water is not limiting. Maize grain yields, however, vary depending on season or planting time. Variation in grain yields is mainly due to differences in temperatures across locations and seasons (Tsimba, Edmeades, Millner, \& Kemp, 2013; Long, Assefa, Schwalbert, \& Ciampitti, 2017). In Bangladesh, autumn planted maize yields better (Islam et al., 2014) but farmers in northern districts prefer planting the crop in late rabi (dry season) after harvesting a dry season crop. When planted in late February or early March, maize crop encounters progressively rising temperatures in the vegetative phase and high temperatures in generative and grain filling stages. Numerous studies (e.g., Schlenker \& Roberts, 2009; Hatfield et al., 2011; Hatfield, 2016) indicate likely yield reduction of maize grain due to climate change induced high temperatures. At the early growth stage of maize when meristem is underground, crop development is largely controlled by soil temperatures (Stone, Sorensen, \& Jamieson, 1998).

Knowledge of phenological development of maize in a given environment is essential for fitting the crop into the cropping system. Understanding of phenological response of maize to changes in environmental conditions helps develop agronomic management options and predict crop's adaptive strategies. In a narrow window of fitting crops in intensive cropping system, deciding on planting time becomes critical because delay in maturity or harvest of a crop may delay in fitting subsequent crops risking reduction of yield. The influence of planting date on maize grain yield potential has been well documented (Gupta, 1985; Bauer \& Carter, 1986; Nafziger, 1994; van Roekel \& Coulter, 2011; Tsimba et al., 2013). Islam et al. (2014) evaluated the yield performance of 4maize hybrids planting in three seasons in northern Bangladesh; but experimental evidence of the variation in maize grain yield due to planting dates is not sufficient for making a firm conclusion. The effect of planting date is also an important factor when late planting may present a smaller planting window in relatively higher latitudes. In 
the CHT where maize is planted not for grain yield but for harvesting young ears at dough stage (R4) for selling in market, delay in harvest loses quality and consequential market demand. Therefore, a better understanding of the requirement of growing degree days (GDD) to phenological events and duration of growth stages and time of harvest is more critical.

The objective of this study was to evaluate spatial and temporal variations in accumulation of thermal time and calendar days required to attaining phenological stages, duration of growth phases and yield of maize hybrid as affected by variable planting dates and locations in Bangladesh.

\section{Materials and Methods}

\subsection{Site Description and Crop Management}

An experiment with a hybrid (PSC 121) of white maize was conducted at 3 locations- Bakichara in Bandarban, Birganj and Kaharol in Dinajpur districts in 2016-17. Locations of experiments are shown in Figure 1.Experimental site in Bandarban valley (Akbar et al., 2016) was surrounded by middle-ranged hills. The two locations in Dinajpur district are not far apart but farmers prefer growing maize in two seasons mutually different from each other. Details of the geographical positions of experimental locations and planting seasons are given in Table 1.

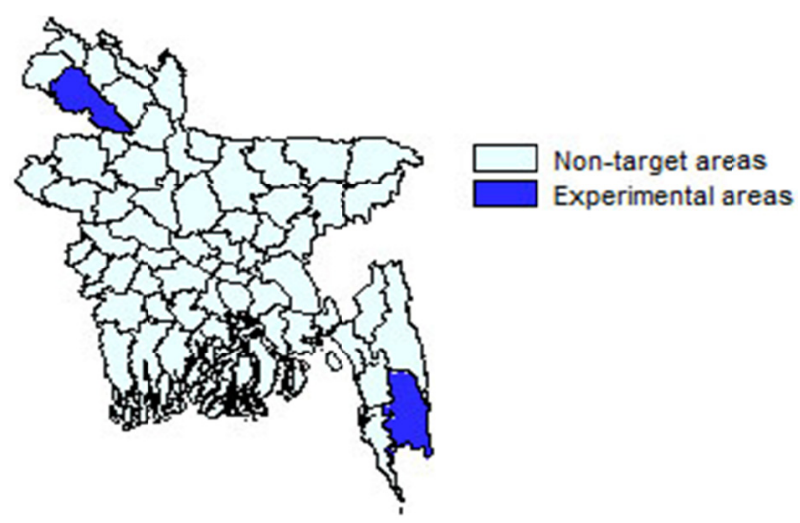

Figure 1. Locations of experiments

Table 1.Experimental locations and maize planting time

\begin{tabular}{lll}
\hline Experiment al location & Geographic coordinates & Planting season, date \\
\hline Bakichara, Bandarban & $22^{\circ} 15^{\prime} 35^{\prime \prime} \mathrm{N}, 92^{\circ} 17^{\prime} 22^{\prime \prime} \mathrm{E}$ & Early rabi season; 27 October, 2016 \\
Birganj, Dinajpur & $25^{\circ} 54^{\prime} 54^{\prime \prime} \mathrm{N}, 88^{\circ} 39^{\prime} 08^{\prime \prime} \mathrm{E}$ & Mid-season; 5 December, 2016 \\
Kaharol, Dinajpur & $25^{\circ} 43^{\prime} 26^{\prime \prime} \mathrm{N}, 88^{\circ} 38^{\prime} 43^{\prime \prime} \mathrm{E}$ & Late rabi season;15 February, 2017 \\
\hline
\end{tabular}

Maize seeds were planted early rabi (atumn/dry season) season in late October 2016 in Bandarban valley, mid-season - 5 December 2016 in Birganj, and late rabi (dry season) 15 February, 2017 in Kaharol. Five plots each measuring $7.0 \mathrm{~m} \times 10.0 \mathrm{~m}$ were established in each location. Maize seeds were planted in rows $0.70 \mathrm{~m}$ apart and $0.20 \mathrm{~m}$ between plants in row giving little over 70,000 plants per ha.

\subsection{Meteorological Data Collection}

Daily data on meteorological parameters for the maize growing season were collected from the Soil and Water Conservation Center, Meghla, some $6 \mathrm{~km}$ from the location of the experiment in Bandarban. Weather data collected from Bangladesh Meteorological Department, Dinajpur station represent the two experimental locations-Birganj and Kaharol. Meteorological observations included daily maximum temperatures and minimum temperatures.

\subsection{Data Collection}

Ten days after emergence ten plants of uniform size were selected from each plot and tagged in each station. Growth stages of maize plants were identified following Abendroth, Elmore, Boyer, and Marlay (2011). Date of seedling emergence $\left(\mathrm{V}_{\mathrm{E}}\right)$, date of 6-leaf stage $\left(\mathrm{V}_{6}\right)$, date of 10-leaf stage $\left(\mathrm{V}_{10}\right)$, date of anthesis or tasseling $\left(\mathrm{V}_{\mathrm{T}}\right)$, 
date of silking $\left(R_{1}\right)$, and date of physiological maturity (R6) were recorded. Number of fully expanded leaves developed in each selected plant was counted daily at 11.00 hrs beginning $\mathrm{V}_{2}$ stage and continued up to $\mathrm{V}_{\mathrm{T}}$ stage Date of silking $\left(\mathrm{R}_{1}\right)$ was recorded at the time when silk emerged in $50 \%$ of the selected plants. Anthesis or tasseling $\left(\mathrm{V}_{\mathrm{T}}\right)$ date was recorded when $50 \%$ of the tagged plants in the plot showed anthers or tassel. Date of silking was recorded when $50 \%$ of the tagged plants in the plot showed silks. Cobs or ears were harvested beyond sampled area every alternate day past dough stage $\left(\mathrm{R}_{4}\right)$ and physiological maturity $\left(\mathrm{R}_{6}\right)$ was recorded when $\geq 50 \%$ of the kernels in the central portion of at least $50 \%$ of five randomly selected ears showed presence of a black layer at the base of the kernel (Daynard \& Duncan, 1969). Since farmers harvest maize at maturity reducing to an ideal grain moisture content of $22-25 \%$ (Thomison, 2010), determining harvest maturity bears practical importance. Harvest maturity was ascertained based on visual observations and qualitative assessment but not quantified reliably. Therefore, discussing phenological data and observations up to $\mathrm{V}_{6}$ stage (physiological maturity) is preferred. Days to attain a given growth stage was calculated based on calendar days and GDD as well. Maize plants terminate vegetative growth developing tassel. Vegetative growth duration was recorded taking time between emergence $\left(\mathrm{V}_{\mathrm{E}}\right)$ and anthesis $\left(\mathrm{V}_{\mathrm{T}}\right)$. Development of 6 leaves $\left(\mathrm{V}_{6}\right)$ and 10 leaves $\left(\mathrm{V}_{10}\right)$ has important bearing on agronomic management practices of maize. Days taken to attain these two events were also counted. Using phenological records, vegetative growing period (VGP), reproductive growing period (RGP) and the maize crop growing period (GP) were calculated. Duration of phenological stages was expressed in days and in growing degree days (GDD). For each location and planting time, duration of different phenological stages of development was calculated based on calendar days and on thermal time using GDD following Equation (1). A base temperature $\left(\mathrm{T}_{\mathrm{b}}\right)$ of $10{ }^{\circ} \mathrm{C}$ was taken for the calculation of GDD for the phenological stages between $\mathrm{V}_{\mathrm{E}}$ and $\mathrm{R}_{1}$ (silking) and $0{ }^{\circ} \mathrm{C}$ for silking to physiological maturity (Tollenaar, Daynard, \& Hunter, 1979; Bonelli, Monzon, Cerrudo, Rizalli, \& Andrade, 2016).

The growing degree days (GDD) were calculated following the equation,

$$
\left.\mathrm{GDD}=\sum(\mathrm{Tmax}+\mathrm{Tmin}) / 2\right)-\mathrm{Tb}
$$

where, $\mathrm{T}_{\max }, \mathrm{T}_{\min }$ and $\mathrm{T}_{\mathrm{b}}$ are the maximum, minimum, and base temperature of $10{ }^{\circ} \mathrm{C}$, respectively, provided that if $\mathrm{T}_{\max }$ is $>30{ }^{\circ} \mathrm{C}$, then $\mathrm{T}_{\max }=30{ }^{\circ} \mathrm{C}$, and if $\mathrm{T}_{\min }<10{ }^{\circ} \mathrm{C}$, then $\mathrm{T}_{\min }=10{ }^{\circ} \mathrm{C}$.

Ears from central 10 rows from each plot were harvested at maturity and sundried for 3 days before threshing. After threshing, kernels were separated, moisture content determined and kernel weight recorded. Yield per unit area was determined harvesting ears from $10 \mathrm{~m}^{2}$ in each plot, sundried, weighed. The grain yield was adjusted at $14 \%$ moisture content.

\subsection{Statistical Analysis}

The experiment comprised 3 treatment variables (i.e., locations) confounded with 3 planting dates (early, midand late rabi season). Five plots in each location formed replications. Data were subjected to statistical analysis using ANOVA following randomized block design. However, the experimental design did not allow detecting location $\mathrm{x}$ planting time interaction effect.

\section{Results and Discussion}

An early maturity maize hybrid, PSC 121 was used in the study. The crop was planted in three environments differing in geographical coordinates and temperature regimes during the growing season. An average maize plant produced a total of $13.2( \pm 0.47)$ leaves and the variation in the number of leaves across locations and planting dates was not statistically significant.

Climatic conditions in general and temperature in particular, influence plant growth and development. Planting time or growing season also plays role in changing environmental conditions that eventually affect crop growth. Geographical factors like latitude regulate environmental conditions of a given location. In the present study, experiments established in diverse locations at three different dates created variable environments. The influence of variable environmental conditions on phenological growth stages of maize was evaluated in the present study. Data on daily maximum and minimum temperatures during the maize growing seasons representing three experimental sites are presented in Figure 2. Data on air temperatures for the two locations (Birganj and Kaharol) in the northern district were taken from the meteorological station, Dinajpur. Start and end dates of the growing seasons at different sites were different. Temperature regimes differed greatly across the locations. Overall temperatures in Bandarban were higher compared with other two locations. Temperatures in Kaharol differed from that of Birganj only due to shift in the growing season. 


\subsection{Location and Planting Time Effects on Maize Phenology}

In all three locations, however, there was considerable overlapping in growing seasons; but there was also significant variation in temperatures across locations (Figure 2). Daily day temperatures were transformed into growing degree days (GDD) for maize. Figure 3 shows the daily accumulation of temperature expressed in GDD in three experimental locations. Compared with Bandarban, experiments in Birganj and Kaharol, located more than $3^{\circ}$ northward, generally experienced cooler temperatures. Marked variation in daily temperature accumulation could be seen during vegetative and early reproductive phase (Figure 3). In Kaharol, maize experienced progressively rising temperatures beginning crop establishment phase that continued till maturity.

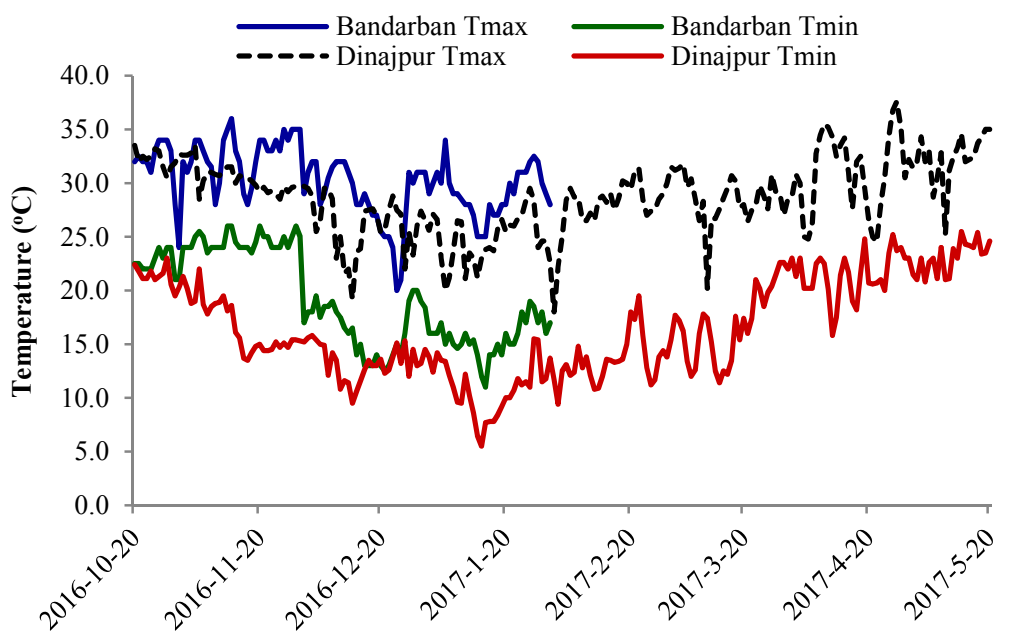

Figure 2. Growing season air temperatures at experimental locations

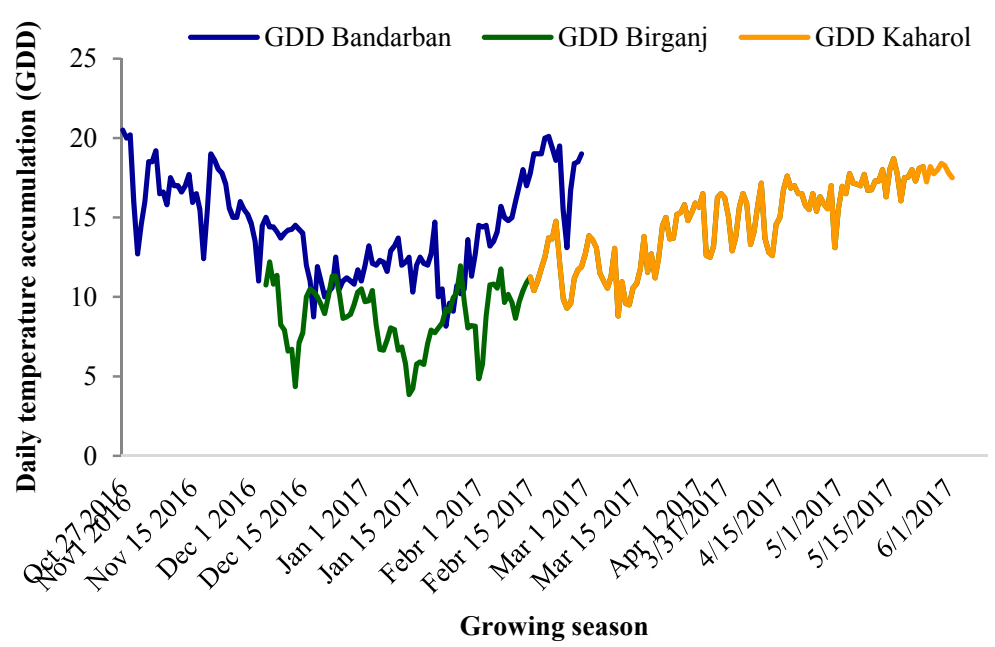

Figure 3. Location and seasonal effect on the variation in daily accumulation of temperature (GDD)

A great deal of variation was observed in days required for attaining phenological stages of maize across locations and planting dates (Figure 4). October planted maize in Bandarban completed life cycle attaining physiological maturity in 116 days. In Birganj, early December planted maize had taken much longer time (149 days). In contrast, late planted crop in Kaharol matured in91days. Ahmad et al. (2016) also reported significant variation in days to attaining different phenological stages due to differences in planting dates. However, the differences become less conspicuous when the duration is converted into accumulated temperatures. Maize seeds planted in October in Bandarban germinated and emerged in 4 days accumulating 71 growing degree days (GDD). Late planted seeds in Kaharol also accumulated 71 GDD in 7 days for emergence. But December planted maize seedlings in Birganj required 88 GDD in 9 days for emergence. Although planted at two different times, temperatures at planting were similar in Bandarban and Kaharol (Figure 2) taking 7 days to germination 
and seedling emergence. Germination, emergence and early stages of maize plant growth till the shoot remaining below the soil surface are more influenced by soil temperatures (Bollero et al., 1996; Stone et al., 1998) rather than air temperatures. Variation in GDD for maize seedling emergence in Bandarban and Birganj can be attributed to differences in post-planting temperatures prevailing in different locations. Our observations are in agreement with Dong, Liu, Tao, Xu, and Wang (2009), and Liu et al. (2013) who reported that heat unit (GDD) requirement for a given growth stage of maize was not constant but varied depending on the changes in environmental conditions due to location and season. October planted crop in Bandarban passed crop establishment phase and the vegetative phase prior to the onset of cool season. Warm soil temperatures and favorable conditions might have accelerated seed germination. Locations in Dinajpur are in higher latitudes northward and had early onset of cool season (Table 1). Kaharol and Birganj are located about $4^{\circ}$ away northward. The December planted maize encountered low temperatures during emergence and early growth phases (Figure 2) that prolonged early vegetative phase. Geographical factor like latitude affects phenology and crop growth significantly modifying weather elements. Liu et al. (2013) demonstrated that in China every $1^{\circ}$ increase in the latitude, northward, the growth and duration of sowing to emergence and emergence to silking increased by $0.7 \mathrm{~d}$ and $1.25 \mathrm{~d}$ respectively as a consequence of lowering temperatures.

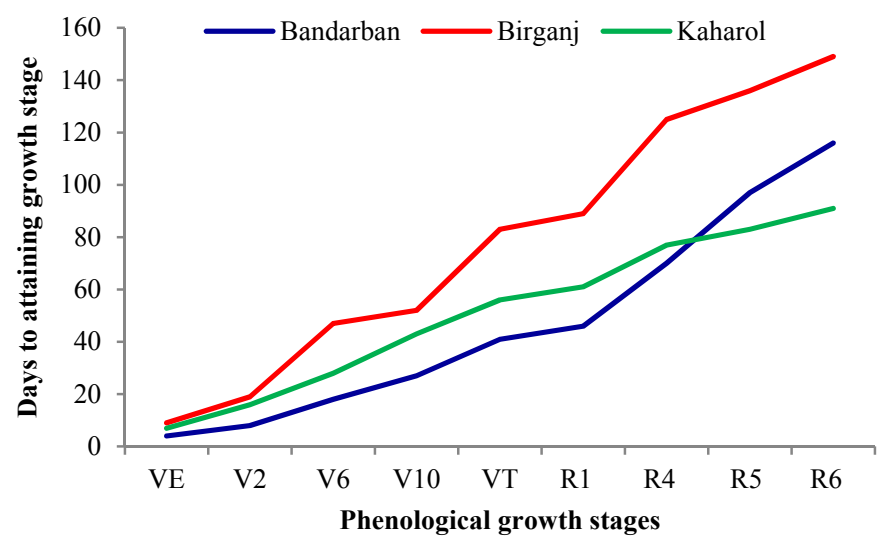

Figure 4. Location and planting date effects on days to attaining phenological sages

Maize phenology is generally divided into vegetative and reproductive phases (Abendroth et al., 2011). Vegetative phase terminates at the appearance of tassel $\left(\mathrm{V}_{\mathrm{T}}\right)$. There was marked variation in days required for vegetative growth $\left(\mathrm{V}_{\mathrm{E}}-\mathrm{V}_{\mathrm{T}}\right)$ phase (Figure 4). Early planted maize in Bandarban required 41 days to attain $\mathrm{V}_{\mathrm{T}}$ while the crop in Birganj took 83 days and 56 days in Kaharol. The difference in thermal time (GDD) across planting dates and locations was less spectacular compared with the differences in calendar days (Figure 5). When Figure 3 and Figure 5 are viewed in conjunction, it becomes apparent that slow accumulation of GDD encountering low temperatures prolonged vegetative growth phase of December planted maize in Birganj. The results are in agreement with that of Liu et al. (2013). In Kaharol also vegetative growth period was slightly longer than it was observed for Bandarban crop. Temperature in Kaharol during early vegetative growth was cooler than it was observed in November in Bandarban. In terms of accumulation of thermal time, GDD for vegetative growth period ranged between 650 and 744 across locations. The results indicate that GDD for maize phenological development is not fixed (Stewart, Dwyer, \& Carrigan, 1998) but varies greatly particularly in vegetative phase. Ahmad et al. (2016) also observed significant variation in thermal time accumulation in attaining phenological stages of maize due to differences in location and planting time. Comparatively lesser variation among planting dates and locations in accumulated temperatures was observed in reproductive $\left(R_{1}\right.$ to $\mathrm{R}_{6}$ ) phase (Figure 5) with nearly a convergence of GDD requirements in attaining $\mathrm{R}_{4}$ (dough) stage. Early and late planted maize in Bandarban and Kaharol took 70 and 77 days, respectively in reaching $\mathrm{R}_{4}$ (dough) stage. But when planted in cool season in Birganj, maize plants required 125 days to attain R4 stage. GDD varied between 721 and 822 for attaining silking stage of maize planted at three planting dates and locations (Figure 6). Wider difference in calendar days spanning from 46 to 89 days for reaching reproductive phase due to different planting dates and across locations can be explained from the variation in atmospheric temperatures during the growing season. Temperatures in Bandarban remained higher throughout growing season compared with Birganj and Kaharol (Figure 2). Maize crop in Bandarban completed major part of vegetative stage prior to the onset of cool season while growth cycle was slow for December planted maize in Birganj that experienced low temperatures, 
i.e., $\mathrm{T}_{\min }<\mathrm{T}_{\mathrm{b}}$ throughout the vegetative phase. In contrast, maize planted in mid-February in Kaharol experienced higher day and night temperatures throughout the growing season that shortened the life cycle of maize.

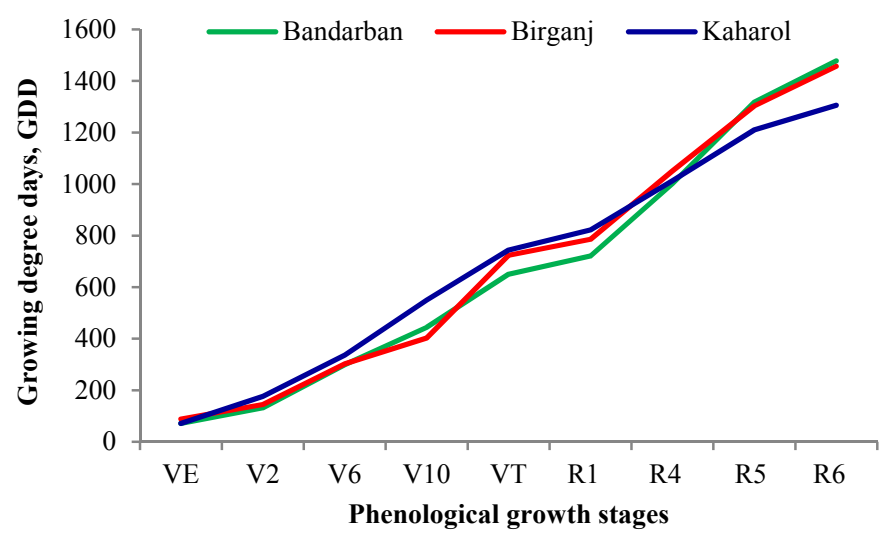

Figure 5. Location and planting date effects on GDD requirement for attaining phenological stages

It is probable that high temperatures might have enhanced phenological development of early planted maize in vegetative phase in Bandarban and exposure of late planted crop in Kaharol to continual high temperatures during the growth cycle increased the rate of phenological development (Hatfield et al., 2011) accelerating growth rate. In contrast, maize planted in Birganj in December encountered low temperature stress during vegetative phase (Figure 2). Temperature lower than $8^{\circ} \mathrm{C}$ during vegetative phase is reported to have caused crop development ceased (Birch et al., 2003).

\subsection{Differences in Phase Duration}

Planting time and location response of maize in the duration of phenological development phases is presented in Figure 6 and Figure 7. As shown in Figure 6, the duration of phenological development stages varied greatly due to geographical location and planting dates. Vegetative growth duration $\left(\mathrm{V}_{\mathrm{E}}-\mathrm{V}_{\mathrm{T}}\right)$ differed from 37 days (in Bandarban) to 74 days (in Birganj), a variation of $100 \%$ between two locations. A reverse trend was observed in the reproductive growth $\left(\mathrm{R}_{1}-\mathrm{R}_{6}\right)$ duration that varied between 30 days (late planting in Kaharol) and 70 days (early planting in Bandarban). Compared to December and February plantings, early planted maize had shorter duration of vegetative phase. December planted maize had longest period of vegetative phase, double that of early planted maize. The opposite trend was observed in the duration of reproductive phase. Late planted maize had the shortest period of reproductive growth. The duration of reproductive growth phase was more than double the vegetative growth duration in the case of October planted maize in Bandarban while February planted maize in Kaharol had about one-third of its life span spent in vegetative phase (Figure 6).

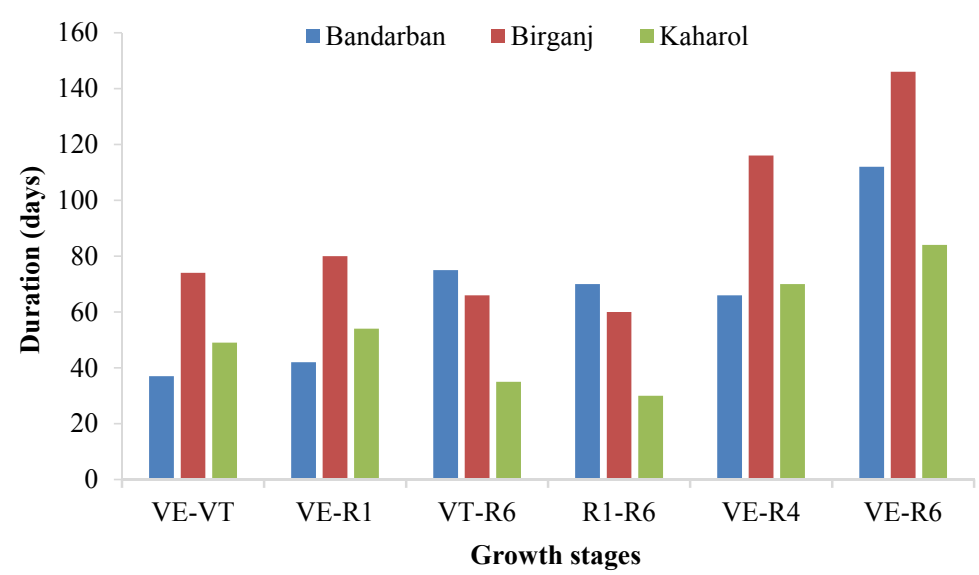

Figure 6. Location and planting date effects on phenological growth stage duration of maize 
Figure 7 shows the thermal time (GDD) required between growth stages of maize planted at different locations and time. The difference in the accumulation of GDD in different growth stages across planting dates and locations was not striking. Accumulated thermal time during vegetative phase varied from 679 GDD (early planting in Bandarban) to 673 GDD (February planting in Kaharol). Delay in planting tended to accumulate more GDD in vegetative phase. In contrast, the total GDD required for attaining physiological maturity (R6) was the highest for October planted maize (1407) and the lowest (1306) for February planted maize suggesting that reproductive growth was shorter for late planted maize. In the early planted maize in Bandarban, GDD accumulation was more (54\%) in the reproductive phase than in vegetative phase while late planted maize in Kaharol had accumulated much less GDD (39\%) in reproductive phase. Figure 7 clearly shows that phenological development in late planted maize in Kaharol was more rapid particularly during post-silking phase. The higher temperatures prevailing during the growing season in Kaharol hastened maturity reducing the duration of phenological development during grain filling stage (Maddonni et al., 1998; Castro-Nava et al., 2011).

Variability in duration of phenological development due to planting date has also been reported by Soler et al. (2005), Liu et al. (2013), and Tsimba et al. (2013). Earlier, Singh et al. (1990) observed maximum variability among sowing dates in duration of phenological development for the emergence to tasseling interval, with the tasseling to silking and silking to maturity intervals being identical for different sowing dates. In this study the influence of location and planting date on phenological development could not be determined independently because of confounding of two factors, but it is probable that geographical location had an influence. Liu et al. (2013) had shown that reproductive growth duration $\left(R_{1}\right.$ to $\left.R_{6}\right)$ decreased by $0.8 \mathrm{~d}$ with each $1^{\circ}$ increase in latitude northward. Figure 7 shows that Birganj and Kaharol being located at higher latitude, the GDD of vegetative growth phase was generally higher and the GDD of reproductive growth duration was lower. Our results agree well with those of Liu et al. (2013). Variation in maize phenology due to shift in planting date might have been due to changes in temperatures (Liu et al., 2013).

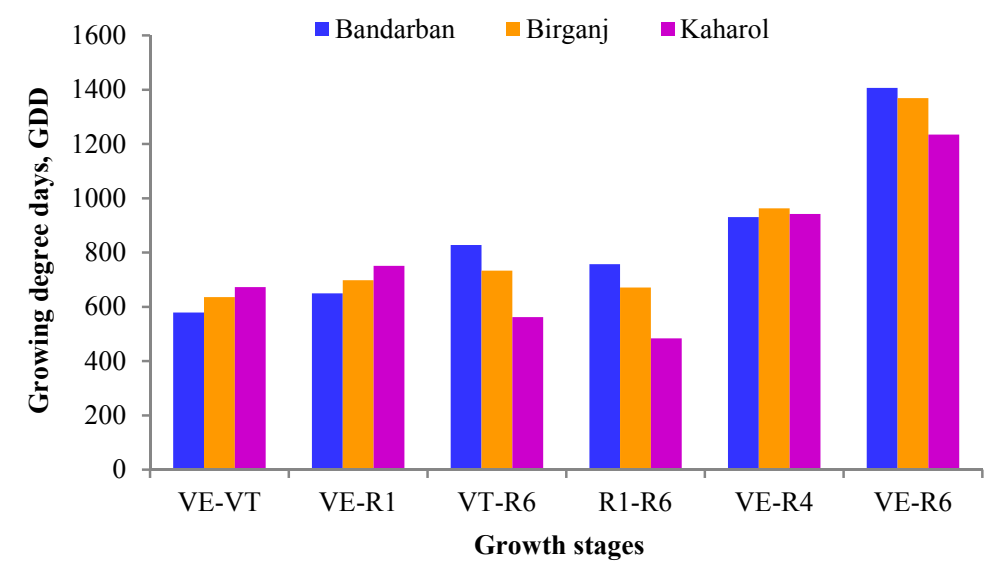

Figure 7. Location and planting date effects on GDD requirements between growth stages of maize

\subsection{Location and Planting Time Effect on Maize Grain Yield}

Data on maize grain yield and yield components as affected by planting date and geographical locations are presented in Table 2. Grain yields varied significantly due to planting time and location. Earlier planted maize in Bandarban produced the highest grain yield $\left(8,564 \mathrm{~kg} \mathrm{ha}^{-1}\right)$ and the February planted maize in Kaharol recorded the lowest yield $\left(4,785 \mathrm{~kg} \mathrm{ha}^{-1}\right)$. Generally, earlier the planting greater was the grain yield. Grain yield of cereal crops is the function of the number of filled-grains per unit area times the individual grain size. Maize grain yield is associated with the number of ears per unit area, number of kernels per ear and 100-kernel weight. As evident from Table 2, planting date and location exerted significant influence on all the yield components. Generally delayed the planting time lower was the yield component value. However, the number of ears did not differ significantly across treatments; but the late planted maize had significantly lower number of kernels per ear and individual kernel size while earlier planted crop had more number of kernels per ear. Late planted maize encountered high temperatures toward the reproductive phase that ranged between 31 and $35^{\circ} \mathrm{C}$ (Figure 2). High temperatures affect reproductive growth accelerating growth rate, shortening growth phases and eventually reducing grain yield. Shim et al. (2017) reported a linear decrease in kernel number with increasing temperatures. In our study, much of the yield reduction 
could have been accounted for the decrease in kernel number per ear. Prolonged exposure to supra-optimal temperatures might have reduced pollen germination and caused poor kernel set (Herrero \& Johnson, 1990; Lizaso et al., 2018) in the late planted maize. Location or geographical coordinates also might have influenced in the variation of yield components (Liu et al., 2013). The ambient temperatures that the mid-February planted maize in Kaharol encountered, particularly during the grain filling period, shortened the reproductive growth and hastened maturity (Figure 6). Reduction in the length of the growth cycle, especially the grain-filling phase, is the most important factor in explaining reduced yields at warmer temperatures (White \& Reynolds, 2003). Higher latitudes of Birganj and Kaharol also might have affected grain yield narrowing the window of growing season (Long et al., 2017).

Table 2. Location and planting date effects on the variation in maize grain yield

\begin{tabular}{lllll}
\hline Location \& planting date & Ears $\left(\right.$ Number $\left.\mathrm{m}^{-2}\right)$ & Kernels $\left(\right.$ Number ear $\left.{ }^{-1}\right)$ & 100 -kernel wt $(\mathrm{g})$ & Grain yield $\left(\mathrm{kg} \mathrm{ha}^{-1}\right)$ \\
\hline Bandarban; 26 Oct. 2015 & 6.67 & 157.35 & 36.837 & 8,064 \\
Birganj; 5 Dec. 2015 & 7.03 & 118.72 & 30.26 & 6,362 \\
Kaharol; 15 Feb. 2016 & 6.80 & 108.2 & 24.87 & 4,785 \\
\hline LSD $_{0.05}$ & ns & 11.315 & 7.607 & 237.02 \\
\hline
\end{tabular}

Yield formation in maize is directly linked to the rate of plant biomass accumulation and partitioning of assimilates to the developing grain. Severini, Borrás, Westgate, and Cirilo (2011) found kernel number per plant highly correlated with ear biomass accumulation around flowering implying that high temperature stress during grain filling might have reduced the kernel number. Grain size or kernel weight largely depends on the current photosynthetic activities and reserve mobilization during grain filling stage (Maddonni et al., 1998). Kernel weight decreased with delay in planting dates with highest reduction in kernel weight in February planted maize mainly due to high temperatures corresponding to grain filling phase. Planting date associated temperature changes was perhaps the primary factor that decreased kernel weight and that eventually reduced grain yield.

It appears that the vegetative growth of late planted maize was less affected compared to reproductive growth due to higher temperatures. Reduction in grain yield of late planted maize in Kaharol might be due to high temperatures, especially during the grain filling phase. Maize crop in Kaharol passed through vegetative stage within the range of optimal temperatures but encountered increasingly higher temperatures in later stages of crop growth (Figure 2). High temperatures generally accelerate crop growth and reduce grain filling period (White \& Reynolds, 2003; Lizaso et al., 2018). It is probable that high temperatures reduced reproductive growth phase and hastened maturity.

The yield reduction in late planted maize might also be associated with source-sink relationship (Bonelli et al., 2016). Maize grain yield is generally sink limited (Gambín, Borrás, \& Otegui, 2007) and source limitations are common only early in kernel development (Gambín, Borrás, \& Otegui, 2006). Kernel number per plant is a physiological function regulating photosynthesis at silking (Edmeades \& Daynard, 1979) and closely related with plant growth rate during the critical period for kernel set (Kiniry \& Ritchie, 1985; Tollenaar et al., 1992). Demonstrating the importance of source availability per kernel during early grain filling on the determination of maize potential sink capacity and final kernel weight, Gambin et al. (2006) suggested that the significant differences in final kernel weight due to variation in location or environment could be explained by the growth rate per kernel around flowering.

\section{Conclusion}

Results of the experiment showed maize phenology differing due to location and planting time. Maize planted in late October in Bandarban had optimal temperatures and attained physiological maturity in 116 days. In contrast, December planted crop in Birganj had extended vegetative phase in cool weather, encountered high temperatures toward grain growth stage and attained physiological maturity in 149 days. February planted maize in Kaharol had supra-optimal temperatures past vegetative stage that hastened growth stages attaining physiological maturity in 91 days. In order for accumulating about 1500 GDD for attaining maturity avoiding supra-optimal temperatures, maize should be planted in Dinajpur preferably in November before the onset of cool season.

\section{References}

Abendroth, L. J., Elmore, R. W., Boyer, M. J., \& Marlay, S. K. (2011). Corn growth and development (PMR1009). Iowa State University Extension, Ames, Iowa. 
Ahmad, I., Basra, S. M. A., Akram, M., Ansar, M., Wasaya, A., \& Hussain, S. A. (2016). Agrometeorological, phenological and yield response of spring maize as influenced by foliar application of different plant growth regulators under suboptimal temperature of Faisalabad, Pakistan. Journal of Agrometeorology, 18(2), 315-319.

Akbar, M. A., Siddique, M. A., Marma, M. S., Rahman, M. M., Molla, M. R. I., Rahman, M., ... Hamid, A. (2016). Planting arrangement, population density and fertilizer application rate for white maize (Zea mays L.) production in Bandarban valley. Agriculture. Forestry and Fishery, 5(6), 215-224. https://doi.org/ 10.11648/j.aff.20160506.12

Bauer, P. J., \& Carter, P. R. (1986). Effect of seeding date, plant density, moisture availability, and soil nitrogen fertility on maize kernel breakage susceptibility. Crop Science, 26, 1220-1226. https://oi.org/10.2135/ cropsci1986.0011183X002600060030x

BBS (Bangladesh Bureau of Statistics). (2018). Yearbook of agricultural statistics 2017. Ministry of Planning, Government of Bangladesh, Dhaka.

Birch, C. J., Rickert, K. G., \& Hammer, G. L. (1998). Modelling leaf production and crop development in maize (Zea mays L.) after tassel initiation under diverse conditions of temperature and photoperiod. Field Crops Research, 58, 81-95. https://doi.org/10.1016/S0378-4290(98)00087-2

Birch, C. J., Robertson, M. J., Humphreys, E., \& Hutchins, N. (2003). Agronomy of maize in Australia-In review and prospect. In C. J. Birch, \& S. R. Wilson (Eds.), Versatile Maize, Golden Opportunities (pp. 45-57). Proceedings, 5th Australian Maize Conference, 18-20 February 2003, Toowoomba, Australia, Maize Association of Australia, Darlington Point, NSW.

Bollero, G. A., Bullock, D. G., \& Hollinger, S. E. (1996). Soil temperature and planting date effects on corn yield, leaf area, and plant development. Agronomy Journal, 88, 385-390. https://doi.org/10.2134/agronj1996.00021 $962008800030005 x$

Bonelli, L. A., Monzon, J. P., Cerrudo, A., Rizzalli, R. H., \& Andrade, F. H. (2016). Maize grain yield components and source-sink relationship as affected by the delay in sowing date. Field Crops Research, 198, 215-225. https://doi.org/10.1016/j.fcr.2016.09.003

Castro-Nava, S., Ramos-Ortíz, V. H., Reyes-Méndez, C. A., Briones-Encinia, F., \& López-Santillán, J. A. (2011). Preliminary field screening of maize landrace germplasm from northeastern Mexico under high temperatures. Maydica, 56(4), 77-82.

Daynard, T. B. (1972). Relationships among black layer formation, grain moisture percentage, and heat unit accumulation in corn. Agronomy Journal, 64, 716-719. https://doi.org/10.2134/agronj1972.000219620064 $00060003 x$

Daynard, T. B., \& Duncan, W. G. (1969). The black layer and grain maturity in corn. Crop Science, 9, $473-476$. https://doi.org/10.2135/cropsci1969.0011183X000900040026x

De Boeck H. J., Kimball, B. A., Miglietta, F., \& Nijs, I. (2012). Quantification of excess water loss in plant canopies warmed with infrared heating. Global Change Biology, 18, 2860-8. https://doi.org/10.1111/ j.1365-2486.2012.02734.x

DeJonge, K. C., Mefford, B. S., \& Chávez, J. L. (2016). Assessing corn water stress using spectral reflectance. International Journal of Remote Sensing, 37, 2294-2312. https://doi.org/10.1080/01431161.2016.1171929

Dong, J., Liu, J., Tao, F., Xu, X., \& Wang, J. (2009). Spatio-temporal changes in annual accumulated temperature in China and the effects on cropping systems, 1980s to 2000. Climate Research, 40, 37-48. https://doi.org/ $10.3354 / \mathrm{cr} 00823$

Edmeades, G. O., \&Daynard, T. B. (1979). The relationship between final yield and photosynthesis at flowering in individual maize plants. Canadian Journal of Plant Science, 59, 585-601. https://doi.org/10.4141/ cjps 79-097

Gambin, B. L., Borras, L., \& Otegui, M. E. (2006). Source-sink relations and kernel weight differences in maize temperate hybrids. Field Crops Research, 95, 316-326. https://doi.org/10.1016/j.fcr.2005.04.002

Gambín, B. L., Borrás, L., \& Otegui, M. E. (2007). Is maize kernel size limited by its capacity to expand? Maydica, 52, 431-441. 
Gourdji, S. M., Sibleyand, A. M., \& Lobell, D. B. (2013). Global crop exposure to critical high temperatures in the reproductive period: Historical trends and future projections. Environmental Research Letters, 8, 024041. https://doi.org/10.1088/1748-9326/8/2/024041

Gupta, S. C. (1985). Predicting corn planting dates for moldboard and no-tillage systems in the Corn Belt. Agronomy Journal, 77, 446-455. https://doi.org/10.2134/agronj1985.00021962007700030021x

Hatfield, J. L. (2016). Increased temperatures have dramatic effects on growth and grain yield of three maize hybrids. Agriculture Environment Letters, 1, 150006. https://doi.org/10.2134/ael2015.10.0006

Hatfield, J. L., Boote, K. J., Kimball, B. A., Ziska, L. H., Izaurralde, R. C., Ort, D., ... Wolfe, D. (2011). Climate impacts on agriculture: Implications for crop production. Agronomy Journal, 103, 351-70. https://doi.org/ 10.2134/agronj2010.0303

Herrero, M. P., \& Johnson, R. R. (1990). High temperature stress and pollen viability of maize. Crop Science, 20, 796-800. https://doi.org/10.2135/cropsci1980.0011183X002000060030x

Islam, M. K., Mahfuz, M. S., Sarker, M. A. I., Ghosh, S., \& Ali, A. S. M. Y. (2014). Effect of seasonal and environmental variation on yield and yield components of hybrid maize. International. Journal of Agricultural Research Innovation \& Technology, 4(2), 1-5. https://doi.org/10.3329/ijarit.v4i2.22635

Kiniry, J. R., \& Ritchie, J. T. (1985). Shade-sensitive interval of kernel number of maize. Agronomy Journal, 77, 711-715. https://doi.org/10.2134/agronj1985.00021962007700050012x

Kumudini, S., Andrade, F. H., Boote, K. J., Brown, G. A., Dzotsi, K. A., Edmeades, G. O., ... Tollenaar, M. (2014). Predicting maize phenology: Intercomparison of functions for developmental response to temperature. Agronomy Journal, 106, 2087-2097. https://doi.org/10.2134/agronj14.0200

Liu, Y., Xie, R., Hou, P., Li, S., Zhang, H., Ming, B., ... Liang, S. (2013). Phenological responses of maize to changes in environment when grown at different latitudes in China. Field Crops Research, 144, $192-199$. https://doi.org/10.1016/j.fcr.2017.11.013

Lizaso, J. I., Ruiz-Ramos, M., Rodríguez, L., Gabaldon-Leal, C., Oliveira, J. A., Lorite, I. J., ... Rodríguez, A. (2018). Impact of high temperatures in maize: Phenology and yield components. Field Crops Research, 216, 129-140. https://doi.org/10.1016/j.fcr.2017.11.013

Long, N. V., Assefa, Y., Schwalbert, R., \& Ciampitti, I. A. (2017). Maize yield and planting date relationship: A synthesis-analysis for US high-yielding contest-winner and field research data. Frontiers in Plant Science, 8 , 2106. https://doi.org/10.3389/fpls.2017.02106

Maddonni, G. A., Otegui, M. E., \&Bonhomme, R. (1998). Grain yield components in maize: II. Postsilking growth and kernel weight. Field Crops Research, 56, 257-264. https://doi.org/10.1016/S0378-4290(97) 00094-4

Major, D. J., Brown, D. M., Bootsma, A., Dupuis, G., Fairey, N. A., Grant, E. A., ... White, R. P. (1983). An evaluation of the corn heat unit system for the short-season growing regions across Canada. Canadian Journal of Plant Science, 63, 121-130. https://doi.org/10.4141/cjps83-012

Nafziger, E. D. (1994). Corn planting date and plant population. Journal of Production Agriculture, 7, 59-69. https://doi.org/10.2134/jpa1994.0059

Ritchie, S. W., \& Hanway, J. J. (1982). How a corn plant develops (Special Report No. 48). Iowa State University of Science and Technology, Cooperative Extension Service.

Schlenker, W., \& Roberts, M. J. (2009). Nonlinear temperature effects indicate severe damages to US crop yields under climate change. Proceedings of National Academy of Sciences, USA, 106, 15594-15598. https://doi.org/10.1073/pnas.0906865106

Severini, A. D., Borrás, L., Westgate, M. E., \& Cirilo, A. G. (2011). Kernel number and kernel weight determination in dent and popcorn maize. Field Crops Research, 120, 360-369. https://doi.org/10.1016/ j.fcr.2010.11.013

Shim, D., Lee, K. J., \& Lee, B. W. (2017). Response of phenology and yield related traits of maize to elevated temperature in a temperate region. Crop Journal, 5, 305-316. https://doi.org/10.1016/j.cj.2017.01.004

Singh, G., Narwal, S. S., Rao, V. U. M., \& Dahiya, D. S. (1990). Effect of sowing date on requirement of growing degree days, heliothermal units and photothermal units, and phenology of winter maize (Zea mays). Indian Journal of Agricultural Sciences, 60, 723-731. 
Stewart, D. W., Dwyer, L. M., \& Carrigan, L. L. (1998). Phenological temperature response of maize. Agronomy Journal, 90, 73-79. https://doi.org/10.2134/agronj1998.00021962009000010014x

Stone, P. (2001). The effects of heat stress on cereal yield and quality. In A. S. Basra (Ed.), Crop responses and adaptations to temperature stress (pp. 243-91). Binghamton, NY: Food Products Press.

Stone, P. J., Sorensen, I. B., \& Jamieson, P. D. (1998). Soil temperature affects growth and development of maize. Proceedings of Agronomy Society of New Zealand, 28, 7-8.

Stone, P. J., Sorensen, I., \& Jamieson, P. D. (1999). Effect of soil temperature on phenology, canopy development, biomass and yield of maize in a cool-temperate climate. Field Crops Research, 63, 169-178. https://doi.org/10.1016/S0378-4290(99)00033-7

Thomison, P. (2010). Corn harvest schedules and dry down rates. C.O.R.N. Newsletter. Ohio State University Extension.

Timsina, J., \& Majumdar, K. (2012). Improved nutrient management in rice-maize cropping systems: A case study. Better Crops South Asia, 6(1), 25-26.

Tollenaar, M. (1977). Sink-source relationships during reproductive development in maize: A review. Maydica, $22,49-75$.

Tollenaar, M., \& Lee, E. A. (2011). Strategies for enhancing grain yield in maize. Plant Breeding Review, 34, 37-82. https://doi.org/10.1002/9780470880579.ch2

Tollenaar, M., Daynard, T. B., \& Hunter, R. B. (1979). Effect of temperature on rate of leaf appearance and flowering date in maize. Crop Science, 19, 363-366. https://doi.org/10.2135/cropsci1979.0011183X0019 $00030022 \mathrm{x}$

Tollenaar, M., Dwyer, L. M., \& Stewart, D. W. (1992). Ear and kernel formation in maize hybrids representing three decades of grain yield improvement in Ontario. Crop Science, 32, 432-438. https://doi.org/10.2135/ cropsci1992.0011183X003200020030x

Tsimba, R., Edmeades, G. O., Millner, J. P., \& Kemp, P. D. (2013). The effect of planting date on maize: Phenology, thermal time durations and growth rates in a cool temperate climate. Field Crops Research, 150, 145-155. https://doi.org/10.1016/j.fcr.2013.05.028

van Roekel, R. R., \& Coulter, J. A.(2011). Agronomic responses of corn to planting date and plant density. Agronomy Journal, 103, 1414-1422. https://doi.org/10.2134/agronj2011.0071

Warrington, I. J., \& Kanemasu, E. T. (1983). Corn growth response to temperature and photoperiod. I. Seedling emergence, tassel initation, and anthesis. Agronomy Journal, 75, 749-754. https://doi.org/10.2134/ agronj1983.00021962007500050008x

Westgate, M. E., Andrade, F. H., \&Otegui, M. E. (2004). Physiology of the corn plant. In S. Wayne, J. Betrán, \& E. C. A. Runge (Eds.), Corn: Origin, History, Technology, and Production (pp. 235-271). John Wiley \& Sons Inc. Hoboken, New Jersey.

White, J. W., \& Reynolds, M. P. (2003). A physiological perspective on modeling temperature response in wheat and maize crops. In J. W. White (Ed.), Modeling temperature response in wheat and maize (pp. 8-17). Proceedings of a Workshop, CIMMYT, El Batán, Mexico, 23-25 April 2001. CIMMYT, Mexico City.

White, M. A., Thornton, P. E., \& Running, S. W. (1997). A continental phenology model for monitoring vegetation responses to inter-annual climatic variability. Global Biogeochemical Cycles, 11(2), 217-234. https://doi.org/10.1029/97GB00330

\section{Copyrights}

Copyright for this article is retained by the author(s), with first publication rights granted to the journal.

This is an open-access article distributed under the terms and conditions of the Creative Commons Attribution license (http://creativecommons.org/licenses/by/4.0/). 